\title{
An Anomalous Left External Jugular Vein Draining into Right Subclavian Vein: A Case Report
}

\author{
Vena Yugular Externa Izquierda Anómala Drenando en la Vena Subclavia Derecha: Reporte de \\ un Caso
}

Rajanigandha, V.; Rajalakshmi, R.; Ranade, A. V.; Pai, M. M.; Prabhu, L. V.; Ashwin, K. \& Jiji, P. J.

\begin{abstract}
RAJANigandha, V.; RAJAlakshMi, R.; RANADE, A. V.; PAI, M. M.; PRABHU, L. V.; ASHWIN, K. \& JIJI, P. J. An anomalous left external jugular vein draining into right subclavian vein: A case report. Int. J. Morphol., 26(4):893-895, 2008.

SUMMARY: Knowledge of the varying drainage patterns of superficial veins of head \& neck, in particular, jugular veins are not only important for anatomists but also for the surgeons operating at this level and to clinicians in general. The variations are important for interventional radiologists too who perform transjugular procedures, such as port implantations and the transjugular intrahepatic portosystemic shunt or selective venous samplings. Results of recent studies report that the superficial veins, especially the external jugular vein (EJV), is been increasingly utilized for cannulation to conduct diagnostic and therapeutic procedures. We report a very unusual presentation of external jugular vein on left side of an embalmed male cadaver. Embryological evaluations of the anomaly was done and compared with available literature which showed that the observed variation is rare.
\end{abstract}

KEY WORDS: External jugular vein; Variations; Jugular venous system.

\section{INTRODUCTION}

External jugular vein has been (EJV) recommended and routinely used for patients undergoing transjugular liver biopsy as it obviates a deep neck puncture, thereby reducing the risk in patients with impaired coagulation (Siegel et al., 1992). External jugular vein is easier to visualize than the internal jugular vein (IJV) and may give a reliable estimate of central venous pressure (Vinayak et al., 2006). Also it is reported that the insertion of permanent catheter for hemodialysis via EJV is a simple and short-time procedure without any severe complications (Skandalos et al., 2005). These are also important medico-legally (Salmeri et al., 1991). Any malformations of the external jugular vein should be suggested preoperatively, as this helps surgeons to plan the operative procedure. The vein and its major tributaries have to be identified and ligated during surgery to prevent excessive bleeding.

\section{CASE REPORT}

During routine dissection for undergraduate students, in the department of Anatomy, Kasturba Medical College, Mangalore, an unusual venous drainage pattern was noticed on left side in a middle aged male cadaver. Left retromandibular vein (RMV) was formed in the substance of parotid gland by the union of maxillary and superficial temporal vein as usual. The RMV continued downwards and joined with the facial vein (FV) to form the common facial vein $(\mathrm{CFV})$ at the angle of mandible. Common facial vein measured $1.5 \mathrm{~cm}$ in length

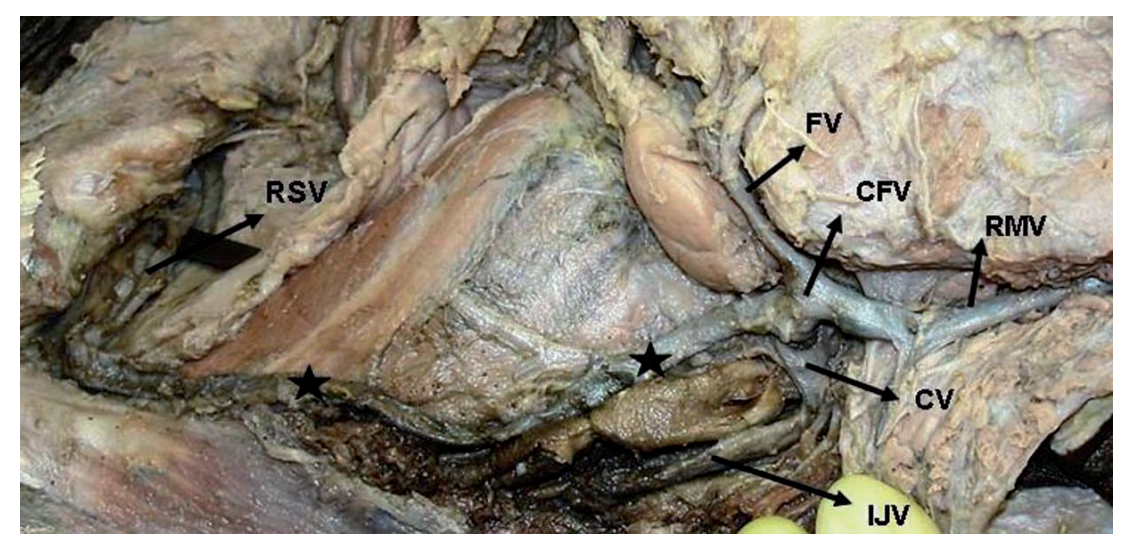

Dissection of the left side of neck showing the anomalous external jugular vein: RMV. Retromandibular vein; FV. Facial vein; CFV. Common facial vein; IJV. Internal jugular vein; CV. Communicating vein with the IJV; RSV. Right Subclavian vein; « - Anomalous external jugular vein. 
and after a short course it bifurcated into two divisions. One of the two divisions was found to follow a peculiar route of termination. The posterior division opened into the internal jugular vein (IJV) through a connecting vein (CV), which passed superficial to common carotid artery. The anterior division then continued downwards and medially as the anomalous EJV, along the anterior border of sternocleidomastoid muscle and reached the jugular notch where it crossed the midline to drain into the opposite (right) subclavian vein (RSV). This vein from point of bifurcation to the termination in right subclavian vein was found to be highly tortous and measured $9.2 \mathrm{~cm}$ in length. All the superficial veins of the left side of neck were draining into the subclavian vein of same side.

\section{DISCUSSION}

The veins of the neck vary considerably in their connections with each other, and in their relative sizes (Hollinshead, 1968). These anomalous patterns differ in their presentation being unilateral or bilateral, as well as between individuals. The venous drainage of head and neck is provided with a paired triple jugular system, comprising of superficial and deep vessels. The IJV being deep and dominant as it drains the brain. The superficial system includes subcutaneous veins; the external and anterior jugulars are especially variable in size and course. As per the standard description EJV begins in the substance of the parotid gland by the union of posterior division of RMV (posterior facial) and the posterior auricular veins or by a single one or some combination of these and the facial, maxillary or other veins near the mandibular angle (Hollinshead,1968). External jugular vein is increasingly being used for therapeutic procedures and monitoring by clinicians. It is often considered as a safer and suitable alternative when the cephalic vein approach is not feasible for totally implantable venous access device (TIVAD) placement (Di Carlo et al., 2005). Yadav et al., (2000) describe a case where the EJV crossed sternocleidomastoid muscle superficially and ended in IJV above the level of superior belly of omohyoid. In contrast to the above mentioned literature, in the present report, EJV on left side is the continuation of the anterior division of CFV, which coursed obliquely downwards to cross the midline and drain into the opposite subclavian vein (right). Moreover, Hollinshead (1982) reports that the EJV usually receives the transverse cervical vein and suprascapular veins. In the present case, these veins were draining into subclavian vein of the same side. The complex embryological development of the vascular system might often result in clinically relevant variations, as in the present case where a normal course of external jugular vein is not present. Chaudhary et al. (1997) has reported a case of anterior facial vein ending as external jugular vein and explained its embryonic development. The veins draining regions of the face and neck establish their identity only after the development of the skull. The external jugular vein is developed from a tributary of the cephalic vein from the tissues of the neck and anastomoses secondarily with the anterior facial vein (Bannister et al., 1995). The cephalic vein at this stage forms a venous ring around the clavicle from which it is connected with the caudal part of the precardinal vein. The deep segment of the venous ring forms the subclavian vein and receives the definitive external jugular vein. The superficial segment of the ring ususually dwindles, but may persist in adult life (Padget, 1957). External jugular vein ends in internal jugular vein in one third of the cases (Hollinshed, 1956). In the present case, it can be hypothesized that external jugular vein failed to develop its posterior connection with the RMV with the persistence of the connection between the common facial and precardinal veins as seen in the $18 \mathrm{~mm}$ stage of the embryo. Knowledge of the varying venous patterns in neck region is of paramount importance for the surgeons in order to avoid unnecessary bleeding during surgical procedures.

RAJANIGANDHA, V.; RAJALAKSHMI, R.; RANADE, A. V.; PAI, M. M.; Prabhu, L. V.; ASHWIN, K. \& JIJI, P. J. Vena yugular externa izquierda anómala drenando en la vena subclavia derecha: Reporte de un caso. Int. J. Morphol., 26 (4): 893-895, 2008.

RESUMEN: El conocimiento de los diferentes patrones de drenaje de las venas superficiales de la cabeza y cuello, en particular, las venas yugulares no sólo son importantes para anatomistas, sino también para los cirujanos que operan a este nivel y para los médicos en general. Las variaciones son importantes también para los radiólogos intervencionistas, quienes realizan procedimientos transyugulares, así como implantaciones portales y portosistémicas transyugulares intrahepáticas o derivación venosa selectiva. Resultados de estudios recientes informan que la venas superficiales, especialmente la vena yugular externa, es cada vez más utilizada para la canulación en diagnósticos y procedimientos terapéuticos. Se reporta una muy inusual variación anatómica de la vena yugular externa del lado izquierdo, presente en un cadáver embalsamado de sexo masculino. Fueron realizadas evaluaciones embriológicas de la anomalía y se compararon con la literatura mostrando que se trata de una variación rara.

PALABRAS CLAVE: Vena yugular externa; Variaciones; Sistema venoso yugular. 
RAJANigandha, V.; RAJAlaKShMi, R.; RANADE, A. V.; PAI, M. M.; PRABHU, L. V.; ASHWIN, K. \& JIJI, P. J. An anomalous left external jugular vein draining into right subclavian vein: A case report. Int. J. Morphol., 26(4):893-895, 2008.

\section{REFERENCES}

Bannister, L. H.; Berry, M. M.; Cellins, P.; Dyson, M.; Dussek, J. E. \& Ferguson, M. W. J. Ed. Gray's Anatomy. $38^{\text {th }}$ Edition. Churchill Livingstone, Edinburgh, London, 1995. p. 327,1578

Chaudhary, R.; Tuli, A. \& Choudhry, S. Facial vein terminating in external jugular vein. An embryological interpretation. Surg. Radiol. Anat., 19(2):73-7, 1997.

Di Carlo, I.; Barbagallo, F.; Toro, T.; Sofia, M.; Lombardo, R. \& Cordio, S. External jugular vein cutdown approach, as a useful alternative, supports the choice of the cephalic vein for totally implantable access device placement. Ann. Surg. Oncol., 12(7):1-4, 2005.

Hollinshead, W. H. Anatomy for surgeons. $2^{\text {nd }}$ Ed. New York, Harper and Row, 1956. pp. 530-1.

Hollinshead, W. H. Anatomy for surgeons: The head and neck. $3^{\text {rd }}$ Ed. New York, Harper and Row Publishers, 1968. p.530.

Hollinshead, W. H. Anatomy for surgeons: The head and neck. 3rd Ed. New York, Harper and Row Publishers, 1982. pp. 467-9.

Padget, D. H. The development of the cranial venous system in man, from the viewpoint of comparative anatomy. Contrib. Embryol. Carnegie Inst. Washington, 36:79140, 1957.

Salmeri, K. R.; Salmeri, K. R.; Bellah, J. R.; Ackerman, N. \& Homer, B. Unilateral congenital aneurysm of jugular, linguo-facial and maxillary vein in a dog. J. Am. Vet. Med. Assoc., 198(4):651-4, 1991.

Siegel, E. L.; Caresio, J. \& Eckard, D. A. Use of the external jugular vein approach for transvenous liver biopsy. $J$. Vasc. Interv. Radiol., 3(2):371-4, 1992.

Skandalos, I. K.; Amvrosiadias, D. M.; Christodoulou, A.; Evangelou, I. N.; Ditsias, F. K. \& Karamoshos, K. N. Catheterization of the external jugular vein for hemodialysis. Khirurgila (Mosk), 11:47-50, 2005.

Vinayak, A. G.; Levitt, J.; Gehlbach, B.; Pohlman, A. S.; Hall, J. B. \& Kress, J. P. Usefulness of the external jugular vein examination in detecting abnormal central venous pressure in critically ill patients. Arch. Intern. Med., 166(19):2132-7, 2006.
Yadav, S.; Ghosh, S. K.; \& Anand, C. Variations of superficial veins of head and neck. Anat. Soc. of India, 49:612, 2000.

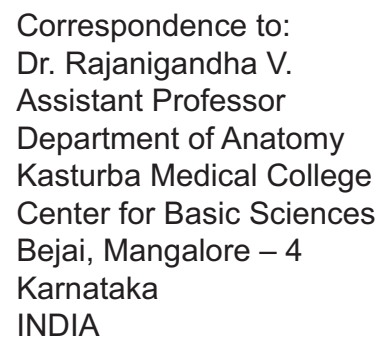

Ph: +91 824 2211746; Fax: +91 8242428183

E-mail: rajaniprajith@yahoo.co.in

Received: 11-12-2007

Accepted: 22-08-2008 
